\title{
Inhaled nitric oxide in patients admitted to intensive care unit with COVID-19 pneumonia
}

\author{
Guido Tavazzi ${ }^{1,2^{*}}$, Marco Pozzi ${ }^{2}$, Silvia Mongodi ${ }^{2}$, Valentino Dammassa ${ }^{1}$, Giovanni Romito ${ }^{1}$ and Francesco Mojoli ${ }^{1,2}$
}

\section{Dear Editor,}

Patients with ARDS due to COVID-19 are characterised by poor oxygenation with a various extent of pulmonary alterations [1]. Ventilation strategies for COVID-19 patients have been suggested basing on the pathophysiological evidence to date [1]; however, there are no data regarding the use of inhaled nitric oxide (iNO). We report herein our experience of iNO administration in COVID-19 mechanically ventilated patients with refractory hypoxaemia and/or right ventricular (RV) dysfunction. Refractory hypoxaemia was defined as $\mathrm{PaO}_{2} / \mathrm{FiO}_{2}<100$ despite high PEEP $(\geq$ $10 \mathrm{cmH}_{2} \mathrm{O}$ ) and prone position. RV dysfunction was defined as acute cor pulmonale at echocardiography with hemodynamic impairment requiring infusion of inotropic drugs [2].

The $\mathrm{NO} /$ nitrogen mixture was introduced into the inspiratory limb of the ventilator tubing. Respiratory and haemodynamic parameters were collected immediately before iNO administration $\left(t_{0}\right)$ and after $15-30 \mathrm{~min}\left(t_{1}\right)$. Responders were defined by an increase of $\mathrm{PaO}_{2} / \mathrm{FiO}_{2}>$ $20 \%$ compared to $t_{0}[3]$.

Results in the text are shown as median [IQR] or number (\%). Wilcoxon test for paired samples and MannWhitney test, as appropriate (MedCalc version 19.2 MedCalc Software), were performed considering $p<0.05$ as significant.

iNO was used in sixteen out of $72(22.2 \%)$ consecutive mechanically ventilated patients (66.0 [59.6-69.7] years

\footnotetext{
* Correspondence: guido.tavazzi@unipv.it

'Department of Clinical-Surgical, Diagnostic and Paediatric Sciences, Unit of Anaesthesia and Intensive Care, University of Pavia, Pavia, Italy

${ }^{2}$ Anesthesia and Intensive Care, Fondazione Policlinico San Matteo Hospital IRCCS, Anestesia e Rianimazione I, DEA Piano -1, Fondazione IRCCS Policlinico S. Matteo, Viale Golgi 19, 27100 Pavia, Italy
}

old; $93 \%$ male). All patients required iNO for refractory hypoxaemia of whom $4(25 \%)$ had also superimposed RV dysfunction, in 1 case associated with pulmonary embolism. The iNO dosage was 25 [20-30] parts per million (ppm).

Respiratory parameters at $t_{0}$ and $t_{1}$ are shown in Table 1. Overall, iNO did not improve oxygenation in our population. Only 4 (25\%) patients were responders, of whom 3 have superimposed RV dysfunction, showing a median increase of $\mathrm{PaO}_{2} / \mathrm{FiO}_{2}$ of 26.9\% [24.1-45.5]. A trend towards a larger improvement of oxygenation was observed in patients with RV dysfunction as compared with those without $\left(\mathrm{PaO}_{2} / \mathrm{FiO}_{2}\right.$ increase $24.1 \%$ [9.2-43.5] vs. 3.3\% [10.8-11.5], $p=0.069$ ). Additionally, in responders, $\mathrm{PaO}_{2} / \mathrm{FiO}_{2}$ was 125.9 [82.2-259.2] at $t_{1}$ and did not change $(p=0.875) 24 \mathrm{~h}$ later (146.4 [102.2-225.1]).

iNO is a free radical gas that diffuses across the alveolar-capillary membrane into the subjacent smooth muscle of pulmonary vessels enhancing endotheliumdependent vasorelaxation and improving oxygenation by increasing blood flow to ventilated lung units [3]. In previous studies, iNO was effective in improving $\mathrm{PaO}_{2} / \mathrm{FiO}_{2}$ and oxygenation index, although it failed in reversing acute lung injury, reducing mechanical ventilation days and mortality [4].

In our population, the improvement of oxygenation in responders was probably magnified by an iNO-induced decrease of RV afterload, enhancing cardiac output and finally leading to an increase of mixed venous oxygen saturation.

Although the reason why patients with refractory hypoxaemia without RV dysfunction were not responder is yet to be determined, some speculation can be done. Severe endothelial injury with cytoplasmic vacuolization 
Table 1 Patients respiratory and hemodynamic parameters at the two time points

\begin{tabular}{|c|c|c|c|}
\hline Parameter & Pre iNO $\left(\boldsymbol{t}_{\mathbf{0}}\right)$ & Post iNO $\left(\boldsymbol{t}_{\mathbf{1}}\right)$ & $\boldsymbol{p}$ value \\
\hline $\mathrm{SBP}, \mathrm{mmHg}$ & $127.0[114.0-137.5]$ & 119.0 [110.0-138.0] & 0.454 \\
\hline MAP, $\mathrm{mmHg}$ & 83.5 [80.5-93.5] & $78.0[74.5-85.5]$ & 0.144 \\
\hline $\mathrm{HR}, \mathrm{bpm}$ & 89.5 [80.5-99.7] & $88.0[75.0-100.0]$ & 0.159 \\
\hline $\mathrm{pH}$ & 7.27 [7.22-7.35] & $7.31[7.24-7.36]$ & 0.049 \\
\hline $\mathrm{PaCO}_{2}, \mathrm{mmHg}$ & $59.8[52.5-76.5]$ & $60.9[50.8-65.7]$ & 0.002 \\
\hline $\mathrm{PaO}_{2}, \mathrm{mmHg}$ & 79.7 [58.9-87.2] & $77.1[63.5-88.6]$ & 0.252 \\
\hline $\mathrm{PaO}_{2} / \mathrm{FiO}_{2}$ & $91.7[62.1-109.2]$ & $91.5[67.1-106.7]$ & 0.274 \\
\hline MetHb, \% & $1.18[1-1.3]$ & $1.3[1.1-1.4]$ & 0.16 \\
\hline $\mathrm{FiO}_{2}$ & 87.5 [80-95] & 87.5 [80-95] & 1 \\
\hline PEEP, $\mathrm{cmH}_{2} \mathrm{O}$ & 13.0 [10.0-15.0] & $13.0[10.0-15.0]$ & 1 \\
\hline $\mathrm{MV}, \mathrm{L} / \mathrm{min}$ & $9.7[8.1-11.3]$ & $10.3[8.7-11.4]$ & 0.204 \\
\hline Peak pressure, $\mathrm{CmH}_{2} \mathrm{O}$ & $30.5[27.5-33.5]$ & $30.5[26.0-33.0]$ & 0.641 \\
\hline
\end{tabular}

Results in the table are shown as mean [Cl 95\%]

$S B P$ systolic blood pressure, MAP mean arterial pressure, $H R$ heart rate, $b p m$ beats per minutes, MetHb methemoglobin, PEEP positive end-expiatory pressure, $M V$ minute volume

and cell detachment in pulmonary middle-small arteries can make the pulmonary vessels less reactive to iNO stimulation $[1,5,6]$. This could also explain the loss of hypoxic vasoconstriction and lung perfusion regulation. However, whether vascular derangements in COVID-19 are due to endothelial cell involvement by the virus, part of the ARDS pathophysiology or the intertwine of both is still undetermined. Moreover, prone position and iNO were used in refractory hypoxaemia as an escalating treatment strategy. Therefore, a positive response to the prone position may have precluded the enrolment in our study of patients that could positively respond to iNO.

\section{Conclusion}

Overall, iNO did not improve oxygenation in COVID-19 patients with refractory hypoxaemia, when administered as a rescue treatment after prone position. A subgroup of patients with RV dysfunction was better iNO responders probably due to the haemodynamic improvement associated with RV unloading.

\section{Acknowledgements}

We thank all the nurses and physicians involved in the management of such epidemics (Dr. Camporotondo Rita, Prof. lotti Giorgio, Dr. Sciutti Fabio, Dr. Rodi Giuseppe, Dr. Orlando Anita, Dr. Maggio Giuseppe, Dr. Belliato Mirko, Dr. Radolovich Danila, Dr. Sala Gallini Giuseppe, Dr. Caneva Luca, Dr. Pagani Michele, Dr.Ferrari Fiorenza, Dr. Aliberti Anna, Dr. Visconti Federico, Dr. Repossi Filippo, Dr. Civardi Luca, Dr. Puce Roberta, Dr. Aliberti Anna, Dr.Bottazzi, Andrea, Dr. Amatu Alessandro, Dr. Lococo Claudia, Dr. Arisi Eric) and the Pavia COVID-19 Task Force (Dr. Marena Carlo, Dr. Calvi Monica, Dr. Grugnetti Giuseppina, Dr. Maurelli Marco, Dr. Muzzi Alba, Prof. Raffaele Bruno, Dr. Lago Paolo, Prof. Marseglia Gianluigi, Prof. Perlini Stefano, Dr. Palo Alessandra, Prof Baldanti Fausto, Prof. Corsico Angelo Guido, Prof. Di Sabatino Antonio, Prof. Iotti Giorgio, Prof. Benazzo Marco, Prof.Carlo Nicora, Prof.Antonio Triarico and Dr. Vincenzo Petronella).

\section{Authors' contributions}

All authors contributed equally to the data collection and redaction, writing and final revision before submission of the paper. The author(s) read and approved the final manuscript.

\section{Funding}

No funding were received for the submitted work.

\section{Availability of data and materials}

The datasets used and/or analysed during the current study are available from the corresponding author on reasonable request.

\section{Ethics approval and consent to participate}

Informed consent was collected following the ad hoc procedures defined by the local Ethics Committee of Fondazione Policlinico San Matteo IRCCS for the COVID-19 pandemic

\section{Competing interests}

FM received fees for lectures from GE Healthcare, Hamilton Medical, SEDA SpA, outside the present work. SM received fees for lectures from GE Healthcare, outside the present work. GT received fees for lectures by GE Healthcare, outside the present work. MP, VD and GR have nothing to disclose.

Received: 22 July 2020 Accepted: 3 August 2020

Published online: 17 August 2020

\section{References}

1. Marini JJ, Gattinoni L. Management of COVID-19 respiratory distress. JAMA. 2020. Online ahead of print.

2. Narendra DK, Hess DR, Sessler CN, Belete HM, Guntupalli KK, Khusid F, Carpati CM, Astiz ME, Raoof S. Update in management of severe hypoxemic respiratory failure. Chest. 2017;152:867-79.

3. Ichinose F, Roberts JD Jr, Zapol WM. Inhaled nitric oxide: a selective pulmonary vasodilator: current uses and therapeutic potential. Circulation. 2004;109:3106-11.

4. Gebistorf F, Karam O, Wetterslev J, Afshari A. Inhaled nitric oxide for acute respiratory distress syndrome (ARDS) in children and adults. Cochrane Database Syst Rev. 2016;2016(6):CD002787.

5. Copin MC, Parmentier E, Duburcq T, Poissy J, Mathieu D, Lille C-I, Anatomopathology G. Time to consider histologic pattern of lung injury to treat critically ill patients with COVID-19 infection. Intensive Care Med. 2020; 46(6):1124-6.

6. Varga Z, Flammer AJ, Steiger $P$, Haberecker M, Andermatt R, Zinkernagel AS, Mehra MR, Schuepbach RA, Ruschitzka F, Moch H. Endothelial cell infection and endotheliitis in COVID-19. Lancet. 2020;395(10234):1417-8.

\section{Publisher's Note}

Springer Nature remains neutral with regard to jurisdictional claims in published maps and institutional affiliations.
Ready to submit your research? Choose BMC and benefit from:
- fast, convenient online submission
- thorough peer review by experienced researchers in your field
- rapid publication on acceptance
- support for research data, including large and complex data types
- gold Open Access which fosters wider collaboration and increased citations
- maximum visibility for your research: over $100 \mathrm{M}$ website views per year
At BMC, research is always in progress.
Learn more biomedcentral.com/submissions 